University of Wollongong

Research Online

Australian Institute for Innovative Materials -

Papers

Australian Institute for Innovative Materials

$1-1-2014$

Three-dimensional-network Li3V2(PO4) 3/C composite as high rate lithium ion battery cathode material and its compatibility with ionic liquid electrolytes

Jiantie $\mathrm{Xu}$

University of Wollongong, jx307@uowmail.edu.au

Shulei Chou

University of Wollongong, shulei@uow.edu.au

Cuifeng Zhou

University Of Sydney

Qinfen Gu

Australian Synchrotron Company

Hua-Kun Liu

University of Wollongong, hua@uow.edu.au

See next page for additional authors

Follow this and additional works at: https://ro.uow.edu.au/aiimpapers

Part of the Engineering Commons, and the Physical Sciences and Mathematics Commons

Research Online is the open access institutional repository for the University of Wollongong. For further information contact the UOW Library: research-pubs@uow.edu.au 


\title{
Three-dimensional-network Li3V2(PO4) 3/C composite as high rate lithium ion battery cathode material and its compatibility with ionic liquid electrolytes
}

\begin{abstract}
A high performance Li3V2(P04)3 cathode material for lithium ion batteries was synthesized by the microwave-assisted hydrothermal method followed by a post annealing process. The synchrotron X-ray diffraction analysis results confirmed that single-phase Li3V2(PO4)3 with monoclinic structure was obtained. Scanning electron microscope and transmission electron microscope images revealed that the as-prepared Li3V 2(PO4)3 was composed of nanowires and microsized particles. Electrochemical results demonstrated that the Li 3V2(PO4)3 electrode measured at $10 \mathrm{C}$ after 500 cycles can deliver discharge capacities of 85.4 mAh g-1 and 103.4 mAh g- 1 , with a capacity retention of $99.3 \%$ and $95.9 \%$, in the voltage ranges of 3.0-4.3 V and 3.0-4.8 V, respectively, indicating good cycling stability. Furthermore, the electrochemical performance of $\mathrm{Li} 3 \mathrm{~V} 2$ (PO4)3 in ionic liquid electrolytes between $3.0 \mathrm{~V}$ and $4.8 \mathrm{~V}$ was also measured.
\end{abstract}

\section{Keywords}

electrolytes, dimensional, liquid, three, ionic, compatibility, its, material, cathode, battery, ion, lithium, rate, high, composite, c, 3, po4, li3v2, network

Disciplines

Engineering | Physical Sciences and Mathematics

\section{Publication Details}

Xu, J., Chou, S., Zhou, C., Gu, Q., Liu, H. K. and Dou, S. X. (2014). Three-dimensional-network Li3V2(P04) $3 / \mathrm{C}$ composite as high rate lithium ion battery cathode material and its compatibility with ionic liquid electrolytes. Journal of Power Sources, 246 (15 January), 124-131.

\section{Authors}

Jiantie Xu, Shulei Chou, Cuifeng Zhou, Qinfen Gu, Hua-Kun Liu, and S X. Dou 


\section{Three Dimensional Structure $\mathrm{Li}_{3} \mathrm{~V}_{2}\left(\mathrm{PO}_{4}\right)_{3} / \mathrm{C}$ Prepared by Microwave Hydrothermal Method as Cathode Material for Lithium Ion Battery}

Jiantie Xu, ${ }^{a}$ Shu-Lei Chou, ${ }^{a}$ * Cuifeng Zhou, ${ }^{b}$ Qin-Fen $G{ }^{c}{ }^{c}$ Hua-Kun Liu ${ }^{a}$ and Shi-Xue Dou ${ }^{a}$

${ }^{a}$ Institute for Superconducting and Electronic Materials, University of Wollongong, Wollongong, NSW 2522, Australia

${ }^{b}$ Australian Centre for Microscopy and Microanalysis, The University of Sydney, NSW 2006, Australia

${ }^{c}$ Australian Synchrotron, 800 Blackburn Rd, Clayton 3168, Australia

*Corresponding author Email: shulei@uow.edu.au

\section{ABSTRACT}

A high rate performance $\mathrm{Li}_{3} \mathrm{~V}_{2}\left(\mathrm{PO}_{4}\right)_{3}$ cathode material for lithium ion batteries was synthesized by the microwave-assisted hydrothermal method followed by a post annealing process. The morphology and structure of $\mathrm{Li}_{3} \mathrm{~V}_{2}\left(\mathrm{PO}_{4}\right)_{3}$ were characterized by scanning electron microscope, transmission electron microscopy and synchrotron x-ray diffraction. Electrochemical results showed that the $\mathrm{Li}_{3} \mathrm{~V}_{2}\left(\mathrm{PO}_{4}\right)_{3}$ electrode measured at $10 \mathrm{C}$ after 500 cycles can deliver discharge capacities of $85.4 \mathrm{mAh} \mathrm{g}^{-1}$ and $107.8 \mathrm{mAh} \mathrm{g}^{-1}$, with capacity retention of $99.3 \%$ and $95.9 \%$, between $3.0-4.3 \mathrm{~V}$ and $3.0-4.8 \mathrm{~V}$, respectively, indicating the good cycling stability. Furthermore, the electrochemical performance of $\mathrm{Li}_{3} \mathrm{~V}_{2}\left(\mathrm{PO}_{4}\right)_{3}$ in ionic liquid electrolytes between $3.0 \mathrm{~V}$ and $4.8 \mathrm{~V}$ were also measured.

Keywords: Lithium ion battery; Cathode materials; $\mathrm{Li}_{3} \mathrm{~V}_{2}\left(\mathrm{PO}_{4}\right)_{3}$; Microwave-assisted hydrothermal method; Ionic liquids.

\section{Introduction}

Since $\mathrm{LiFePO}_{4}$ was proposed as a cathode material for the lithium ion battery by Goodenough et al. [1] in 1997, it has been widely viewed as one of the most promising for large-scale commercialization because of its high capacity, thermal stability, environmental benignity, and low cost [2]. Other lithium transition metal phosphates including $\mathrm{LiMPO}_{4}(\mathrm{M}=\mathrm{Mn}, \mathrm{Co}$, 
Ni) $[3,4], \mathrm{Li}_{3} \mathrm{~V}_{2}\left(\mathrm{PO}_{4}\right)_{3}[5,6], \mathrm{LiVOPO}_{4}[7,8], \mathrm{Li}_{9} \mathrm{M}_{3}\left(\mathrm{PO}_{4}\right)_{2}\left(\mathrm{P}_{2} \mathrm{O}_{7}\right)_{3}(\mathrm{M}=\mathrm{V}, \mathrm{Cr}, \mathrm{Al}, \mathrm{Ga})[9,10]$, $\mathrm{Li}_{2} \mathrm{MP}_{2} \mathrm{O}_{7}(\mathrm{M}=\mathrm{Mn}, \mathrm{Co}, \mathrm{Fe})[11,12]$ and their derivatives [13-15], have also received a lot of attention due to their great thermal stability and competitive energy density. For one particular, $\mathrm{Li}_{3} \mathrm{~V}_{2}\left(\mathrm{PO}_{4}\right)_{3}$ shows higher theoretical capacity $\left(\sim 197 \mathrm{mAh} \mathrm{g}^{-1}\right.$ vs. $\sim 166 \mathrm{mAh} \mathrm{g}^{-1}$ for $\left.\mathrm{LiFePO}_{4}\right)$ and higher average operation voltage plateau $\left(\sim 4.0 \mathrm{~V}\right.$ vs. $\sim 3.5 \mathrm{~V}$ for $\left.\mathrm{LiFePO}_{4}\right)$, leading to its higher energy density $\left(\sim 800 \mathrm{Wh} \mathrm{g}^{-1}\right.$ vs. $\sim 560 \mathrm{Wh} \mathrm{g}^{-1}$ for $\left.\mathrm{LiFePO}_{4}\right)[1,5]$. However, the low intrinsic electronic conductivity $\left(\sim 2.4 \times 10^{-7} \mathrm{~s} \mathrm{~cm}^{-1}\right)$, high working potential (up to $4.8 \mathrm{~V}$ ) and low $\mathrm{Li}^{+}$diffusion coefficient $\left(10^{-9} \sim 10^{-10} \mathrm{~cm}^{2} \mathrm{~s}^{-1}\right)$ of $\mathrm{Li}_{3} \mathrm{~V}_{2}\left(\mathrm{PO}_{4}\right)_{3}$ leads to a poor high rate performance and unstable electrolyte, and thus limits its practical application [16]. To improve the high rate capabilities of $\mathrm{Li}_{3} \mathrm{~V}_{2}\left(\mathrm{PO}_{4}\right)_{3}$, there have been a few reports on $\mathrm{Li}_{3} \mathrm{~V}_{2}\left(\mathrm{PO}_{4}\right)_{3}$ in morphologies control, such as nanofibers [17], nanorods [18], nanoplates [19], nanobelts [20] and nanoporous [21] through various preparation methods and it is proved to be an effective way to improve the high rate capabilities of electrode materials. However, the large amount of nanosize materials with high surface area will reduce the volumetric energy densities of lithium ion batteries and improve the side reaction between active materials and electrolyte. Therefore, the micrometer-size particles consisting of aggregated nanometer-size particles, plates or wires is the ideal morphology for the electrode materials for lithium ion batteries with high energy densities at high C-rates [22].

Furthermore, to reach the high theoretical specific capacity $\left(\sim 197 \mathrm{mAh} \mathrm{g}^{-1}\right)$, the $\mathrm{Li}_{3} \mathrm{~V}_{2}\left(\mathrm{PO}_{4}\right)_{3}$ electrode must be fully charged to $\sim 4.8 \mathrm{~V}\left(\mathrm{~V}^{3+} \rightarrow \mathrm{V}^{5+}\right)$. Conventional electrolytes $\left(\mathrm{LiPF}_{6}\right.$ in ethylene carbonate: diethyl carbonate (EC:DEC) or EC: dimethyl carbonate $(\mathrm{DMC}))$, however, will decompose at such voltage $(>4.6 \mathrm{~V})$. The electrolyte decomposition will severely increase the explosion and fire risk of lithium ion batteries. Ionic liquids (ILs), on the other hand, have been receiving greater attention in the lithium ion battery field because of their non-flammability, negligible vapour pressure, and high thermal, chemical, and electrochemical stability. Among the large family of ILs, pyrrolidinium bis(trifluoromethanesulfonyl) amide salts in particular show high cathodic stability against lithium metal, relatively high ionic conductivity, non-flammability and also good electrochemical properties in battery tests [23-25]. 
The microwave assisted hydrothermal method is widely used because of combination of advantages of the conventional hydrothermal method [26-28] and microwave solid-state synthesis [29, 30], including morphology control, low cost, short reaction time, and high efficiency. Here, we successfully adopted a new synthesis route based on the microwave assisted hydrothermal method to obtain three dimensional (3D) $\mathrm{Li}_{3} \mathrm{~V}_{2}\left(\mathrm{PO}_{4}\right)_{3} / \mathrm{C}$ micro-size network morphology. The electrochemical performance of $\mathrm{Li}_{3} \mathrm{~V}_{2}\left(\mathrm{PO}_{4}\right)_{3}$ measured in conventional electrolyte and ionic liquids are also compared.

\section{Experimental Section}

The schematic representation of the preparation of $3 \mathrm{D} \mathrm{Li}_{3} \mathrm{~V}_{2}\left(\mathrm{PO}_{4}\right)_{3} / \mathrm{C}$ nanowire and nanoparticle network morphology is illustrated in Figure 1(a). First of all, 0.0075 mol lithium acetate hydrate $\left(\mathrm{CH}_{3} \mathrm{COOLi} \cdot 2 \mathrm{H}_{2} \mathrm{O}\right), 0.005$ mol ammonium metavanadate $\left(\mathrm{NH}_{4} \mathrm{VO}_{3}\right)$ and $0.0075 \mathrm{~mol}$ ammonium dihydrogen phosphate $\left(\mathrm{NH}_{4} \mathrm{H}_{2} \mathrm{PO}_{4}\right)$ were dissolved in $20 \mathrm{~mL}$ distilled water to form a solution. $0.228 \mathrm{~g}$ glucose and $1 \mathrm{~mL}$ of ethylene glycol (EG) were then added to the solution. The solution was stirred for $2 \mathrm{~min}$ before being transferred into a $100 \mathrm{~mL}$ Teflon-lined microwave vessel. The microwave vessel was sealed, kept at $180{ }^{\circ} \mathrm{C}$ for $15 \mathrm{~min}$ in a microwave oven, and then cooled to room temperature naturally. After that, the solution with its black suspension was heated under continuous stirring in an $80^{\circ} \mathrm{C}$ thermostatic water bath for several hours to remove the excess water. Finally, the powder was annealed at $750{ }^{\circ} \mathrm{C}$ for $10 \mathrm{~h}$, with a heating rate of $5{ }^{\circ} \mathrm{C} \mathrm{min}^{-1}$ under high purity Ar atmosphere and then cooled down to room temperature under the same Ar atmosphere.

Synchrotron powder XRD data for Rietveld analysis was collected at room temperature over the range of $3^{\circ}-86^{\circ}$ with a Mythen detector on Powder diffraction beamline at the Australian Synchrotron. The morphology of the $\mathrm{Li}_{3} \mathrm{~V}_{2}\left(\mathrm{PO}_{4}\right)_{3} / \mathrm{C}$ was examined by a high resolution field emission scanning electron microscope (SEM; JEO: FESEM-7500, 30 kV) and transmission electron microscope (TEM; JEO: 2200FS, $200 \mathrm{kV}$ ). The carbon content of the $\mathrm{Li}_{3} \mathrm{~V}_{2}\left(\mathrm{PO}_{4}\right)_{3} / \mathrm{C}, \sim 6.47 \%$, was obtained by thermogravimetric analysis (TGA, Mettler

Toledo). The specific surface area, $11.9 \mathrm{~m}^{2} \mathrm{~g}^{-1}$, was measured by the Brunauer-Emmett-Teller (BET) method on a Quanta Chrome Nova 1000. 
The cathodes were fabricated by blending the $\mathrm{Li}_{3} \mathrm{~V}_{2}\left(\mathrm{PO}_{4}\right)_{3} / \mathrm{C}$ with acetylene black carbon and PVDF, at a weight ratio of 8:1:1, respectively. N-methyl-2-pyrrolidone (NMP) was used as the blending solvent for the mixture. The slurries were prepared using a Kurabo MAZERUSTAR planetary mixer KK-250S for $15 \mathrm{~min}$. The dried electrodes were loaded of about $7 \mathrm{mg}$ of active materials. CR 2032 coin-type cells were assembled using $\mathrm{Li}_{3} \mathrm{~V}_{2}\left(\mathrm{PO}_{4}\right)_{3} / \mathrm{C}$ as the working electrode, Li foil as the counter electrode and reference electrode, porous polypropylene film as separator and $1 \mathrm{M} \mathrm{LiPF}_{6}$ in a 1:2 (v/v) mixture of ethylene carbonate (EC) and diethyl carbonate (DEC), or $1 \mathrm{M}$ lithium bis(trifluoromethanesulfonyl)imide $\left(\operatorname{LiNTf}_{2}\right)$ in N-butyl-N-methyl-pyrrolidinium bis(trifluoromethanesulfonyl)imide $\left(\left[\mathrm{C}_{4} \mathrm{mpyr}\right]\left[\mathrm{NTf}_{2}\right]\right)$, or $1 \mathrm{M}$ lithium bis(trifluoromethanesulfonyl)imide $\left(\operatorname{LiNTf}_{2}\right)$ in $\mathrm{N}$-methyl-N-propylpyrrolidinium bis(trifluoromethanesulfonyl)imide $\quad\left(\left[\mathrm{C}_{3} \mathrm{mpyr}\right]\left[\mathrm{NTf}_{2}\right]\right)$ ionic liquids as the three different kinds of electrolyte. The cells were galvanostatically charged and discharged using an automatic battery tester system (Land ${ }^{\circledR}$, China) at various current densities in the range of $3.0-4.3$ and $3.0-4.8 \mathrm{~V}$ at room temperature and at current densities with various C-rates, with a theoretical specific capacity $\mathrm{C}=140$ and $197 \mathrm{mAh} \mathrm{g}^{-1}$, respectively. The cyclic voltammetry was measured using Biologic VPM3 electrochemical workstation.

\section{Results and discussions}



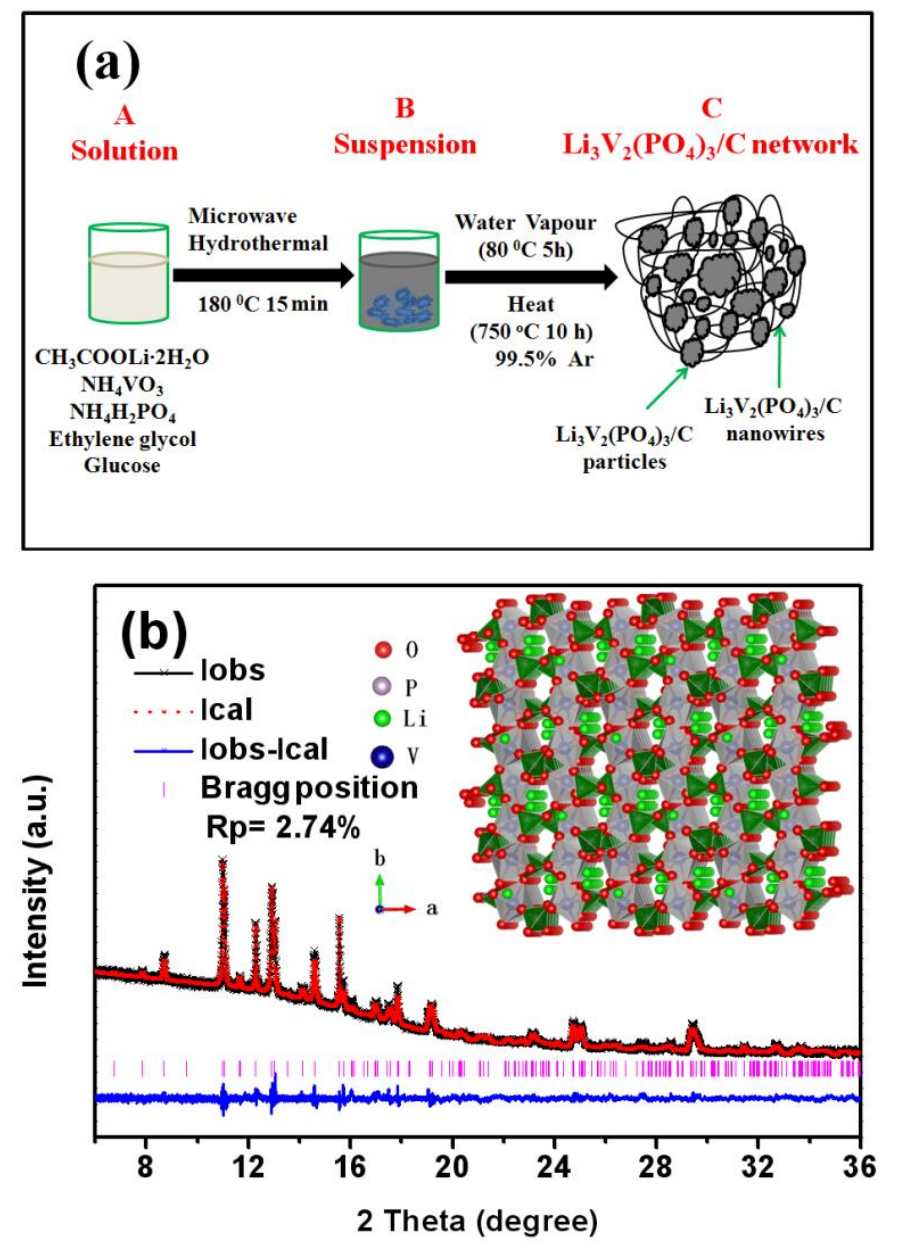

Figure 1. (a) Schematic representation of formation mechanism of $3 \mathrm{D} \mathrm{Li}_{3} \mathrm{~V}_{2}\left(\mathrm{PO}_{4}\right)_{3}$ nanowire and nanoparticle network system. (b) SXRD Rietveld refinement of $\mathrm{Li}_{3} \mathrm{~V}_{2}\left(\mathrm{PO}_{4}\right)_{3}$, where the observed data are indicated by the black symbols and the calculated profile is the red dotted line overlaying them. The lower curve is the difference between the observed and calculated intensities at each step, plotted on the same scale and shifted a little downwards for clarity. Inset of Figure 1: the crystal structure of $\mathrm{Li}_{3} \mathrm{~V}_{2}\left(\mathrm{PO}_{4}\right)_{3}$ based on the SXRD refinement.

Since small amounts of impurities affect the electrochemical properties, the precise XRD pattern was important for obtaining the details of the crystal structure. Figure 1(b) shows the Rietveld refinement results of the synchrotron X-ray diffraction (SXRD) data for $\mathrm{Li}_{3} \mathrm{~V}_{2}\left(\mathrm{PO}_{4}\right)_{3} / \mathrm{C}$ compound sintered at $750{ }^{\circ} \mathrm{C}$, and a space group $\mathrm{P} 2{ }_{1} / \mathrm{n}$ was chosen as the refinement model. The reasonably small profile $\mathrm{R}$-factor, $\mathrm{R}_{\mathrm{p}}$ factor $(\sim 2.74 \%)$, suggests that single-phase $\mathrm{Li}_{3} \mathrm{~V}_{2}\left(\mathrm{PO}_{4}\right)_{3} / \mathrm{C}$ can be obtained with our experimental process. The cell parameters are $\mathrm{a}=8.6291(8) \AA, \mathrm{b}=12.0818(6) \AA, \mathrm{c}=8.6414(2) \AA, \beta=90.022(1)^{\mathrm{o}}$ and the 
unit-cell volume is $900.927(3) \AA^{3}$. The cell parameters are consistent with previous report [31-33]. The detailed atomic coordination of $\mathrm{Li}_{3} \mathrm{~V}_{2}\left(\mathrm{PO}_{4}\right)_{3} / \mathrm{C}$ from the SXRD refinement is listed in Table 1.

Table 1. Atomic position and occupancy of refined $\mathrm{Li}_{3} \mathrm{~V}_{2}\left(\mathrm{PO}_{4}\right)_{3} / \mathrm{C}$.

\begin{tabular}{|c|c|c|c|c|c|c|}
\hline Atom & Multiplicity & $\mathrm{x}$ & Y & Z & $\mathrm{U}_{\text {iso }}(\times 100)$ & Occupancy \\
\hline V1 & 4 & $0.2510(2)$ & $0.4593(5)$ & $0.1093(6)$ & $0.77(2)$ & 1 \\
\hline V2 & 4 & $0.7530(2)$ & $0.4745(1)$ & $0.3903(1)$ & $0.74(2)$ & 1 \\
\hline $\mathrm{P} 1$ & 4 & $0.1069(4)$ & $0.0996(1)$ & $0.1586(5)$ & $1.7(1)$ & 1 \\
\hline $\mathrm{P} 2$ & 4 & $0.6078(2)$ & $0.1149(2)$ & $0.3552(1)$ & $1.7(1)$ & 1 \\
\hline P3 & 4 & $0.0395(1)$ & $0.2509(2)$ & $0.4885(4)$ & $1.7(1)$ & 1 \\
\hline $\mathrm{O} 1$ & 4 & $0.9276(3)$ & $0.1163(3)$ & $0.1463(5)$ & $1.5(2)$ & 1 \\
\hline $\mathrm{O} 2$ & 4 & $0.1482(2)$ & $0.9769(4)$ & $0.2404(1)$ & $1.5(2)$ & 1 \\
\hline $\mathrm{O} 3$ & 4 & $0.1727(3)$ & $0.0516(5)$ & $0.0346(1)$ & $1.5(2)$ & 1 \\
\hline $\mathrm{O} 4$ & 4 & $0.1618(2)$ & $0.2609(4)$ & $0.1845(0)$ & $1.5(2)$ & 1 \\
\hline O5 & 4 & $0.4229(2)$ & $0.0912(5)$ & $0.3267(0)$ & $1.5(2)$ & 1 \\
\hline O6 & 4 & $0.6959(1)$ & $0.0045(2)$ & $0.2841(4)$ & $1.5(2)$ & 1 \\
\hline $\mathrm{O} 7$ & 4 & $0.6416(1)$ & $0.0876(1)$ & $0.4772(4)$ & $1.5(2)$ & 1 \\
\hline O8 & 4 & $0.6437(1)$ & $0.2933(1)$ & $0.3143(1)$ & $1.5(2)$ & 1 \\
\hline O9 & 4 & $0.9509(2)$ & $0.1284(1)$ & $0.5695(5)$ & $1.5(2)$ & 1 \\
\hline $\mathrm{O} 10$ & 4 & $0.9307(4)$ & $0.3194(0)$ & $0.4028(2)$ & $1.5(2)$ & 1 \\
\hline O11 & 4 & $0.1725(4)$ & $0.1635(1)$ & $0.4314(5)$ & $1.5(2)$ & 1 \\
\hline $\mathrm{O} 12$ & 4 & $0.1059(7)$ & $0.3662(4)$ & $0.5761(1)$ & $1.5(2)$ & 1 \\
\hline Li1 & 4 & $0.2020(6)$ & $0.7810(1)$ & $0.1820(2)$ & $0.6(1)$ & 1 \\
\hline Li2 & 4 & $0.9340(5)$ & $0.3120(6)$ & $0.2260(7)$ & $3.6(2)$ & 1 \\
\hline Li3 & 4 & $0.5760(1)$ & $0.4290(1)$ & $0.2070(5)$ & $5.8(1)$ & 1 \\
\hline
\end{tabular}

Space group: $\mathrm{P} 21 / \mathrm{n}$ 
$\mathrm{a}=8.6291(8) \AA, \mathrm{b}=12.0818(6) \AA, \mathrm{c}=8.6414(2) \AA, \beta=90.022(1)^{\mathrm{o}}$ and $\mathrm{V}=900.927(3) \AA^{3}$

Reliable factors: $\mathrm{Rp}=2.74 \%, \mathrm{Rwp}=4.01 \%$.
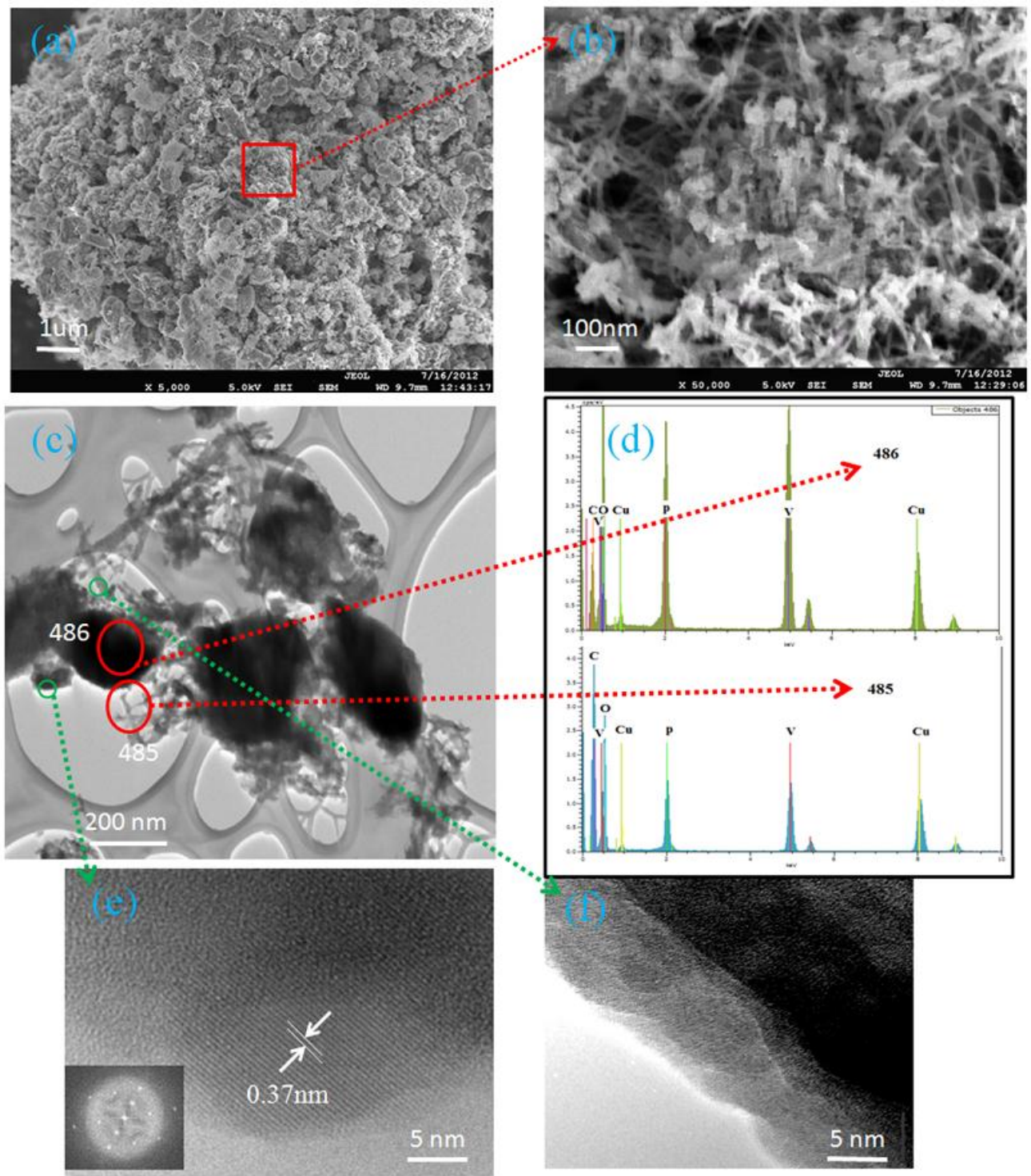

Figure 2. (a, b) SEM and (c) TEM images of $\mathrm{Li}_{3} \mathrm{~V}_{2}\left(\mathrm{PO}_{4}\right)_{3} / \mathrm{C}$; and (d) EDS spectra corresponding to the circled areas in $(\mathrm{d})$; $(\mathrm{e}, \mathrm{f})$ Corresponding HRTEM image from the marked regiqion showing the sigle-crystalline structure is maintained. Inset: Fourier transform image of (e) .

The SEM image of $\mathrm{Li}_{3} \mathrm{~V}_{2}\left(\mathrm{PO}_{4}\right)_{3} / \mathrm{C}$ in Figure 2(a) shows that the bulk $\mathrm{Li}_{3} \mathrm{~V}_{2}\left(\mathrm{PO}_{4}\right)_{3} / \mathrm{C}$ was made up of agglomerated uniform micro-sized particles. Nanowires with $\sim 50 \mathrm{~nm}$ diameter and big particles can be found in Figure 2(b). Moreover, transmission electron microscopy (TEM) and energy dispersive X-ray spectroscopy (EDS) were conducted to further confirm 
the microstructure of $\mathrm{Li}_{3} \mathrm{~V}_{2}\left(\mathrm{PO}_{4}\right)_{3} / \mathrm{C}$. As shown in Figure 2(c) and (d), the selected areas all exhibit the characteristic peaks of $\mathrm{V}, \mathrm{P}, \mathrm{C}$, and $\mathrm{O}$ in the sample. The intensities of the peak are related with the contents of the elements as we selected the spot for analysis without carbon covering in the TEM grid for both $\mathrm{Li}_{3} \mathrm{~V}_{2}\left(\mathrm{PO}_{4}\right)_{3}$ particles and nanowires. The nanowires show much higher intensity of carbon peak than particle sharp materials, indicating much higher carbon contents in nanowires structure. HRTEM and Fourier transform images were shown in the Figure 2(e), the $\mathrm{Li}_{3} \mathrm{~V}_{2}\left(\mathrm{PO}_{4}\right)_{3} / \mathrm{C}$ particle was well crystallized with small amount of amorphous carbon coating. Meanwhile, as HRTEM image shown Figure 2(f), the nanowires of the sample $\mathrm{Li}_{3} \mathrm{~V}_{2}\left(\mathrm{PO}_{4}\right)_{3} / \mathrm{C}$ are composed of large amount of carbon, which provide the $3 \mathrm{D}$ conducting matrix to improve the electron transporting along the nanowires. Meanwhile, the crystalized $\mathrm{Li}_{3} \mathrm{~V}_{2}\left(\mathrm{PO}_{4}\right)_{3} / \mathrm{C}$ particles are acting as the host of lithium ion.
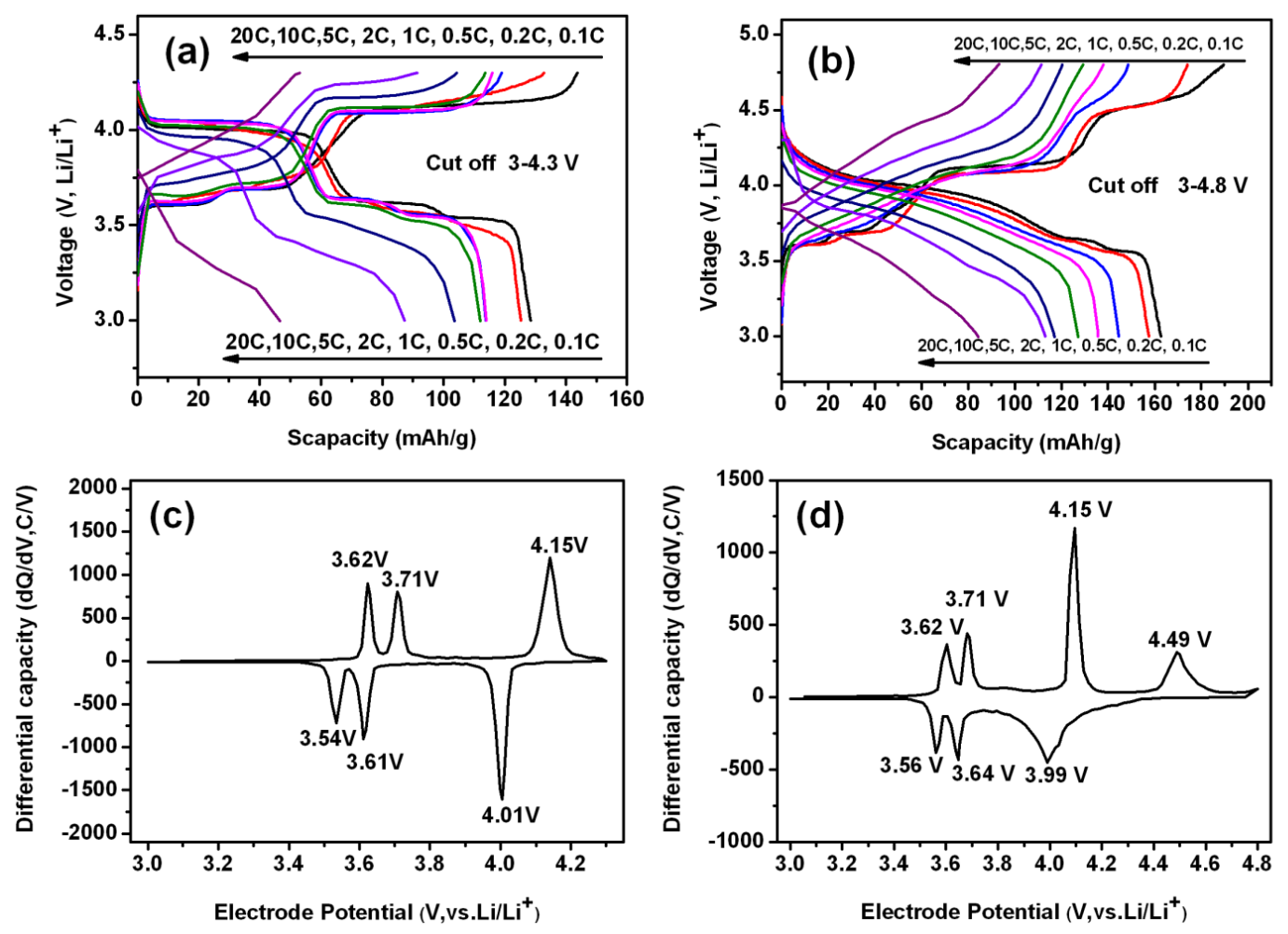

Figure 3. Initial charge-discharge curves $(a, b)$ and $d Q / d V(c, d)$ for $\mathrm{Li}_{3} \mathrm{~V}_{2}\left(\mathrm{PO}_{4}\right)_{3} / \mathrm{C}$ in the voltage ranges of $3.0-4.3 \mathrm{~V}(\mathrm{a}, \mathrm{c})$ and $3.0-4.8 \mathrm{~V}(\mathrm{~b}, \mathrm{~d})$.

Figure 3(a, b) shows typical charge/discharge profiles of $\mathrm{Li}_{3} \mathrm{~V}_{2}\left(\mathrm{PO}_{4}\right)_{3} / \mathrm{C}$ in the voltage ranges of $3.0-4.3 \mathrm{~V}$ and $3.0-4.8 \mathrm{~V}$, respectively, at various current rates. As shown in Figure $3(a, b)$, along with increased charging/discharging current densities, these plateaus 
become shorter, and the difference potential $(\Delta \mathrm{V})$ between the charging and discharging plateaus increases gradually, because of the electrode polarization at high C-rates. The differential capacity vs. voltage $(\mathrm{dQ} / \mathrm{dV})$ curves for $\mathrm{Li}_{3} \mathrm{~V}_{2}\left(\mathrm{PO}_{4}\right)_{3} / \mathrm{C}$ in the voltage ranges of 3.0 - $4.3 \mathrm{~V}$ and $3.0-4.8 \mathrm{~V}$ are shown in Figure 3(c, d), respectively. $\mathrm{Li}_{3} \mathrm{~V}_{2}\left(\mathrm{PO}_{4}\right)_{3} / \mathrm{C}$ presents three pairs of oxidation and reduction peaks in the voltage range of $3.0-4.3 \mathrm{~V}$, while four oxidation peaks and three reduction peaks are observed in the voltage range of $3.0-4.8 \mathrm{~V}$, corresponding to the relevant extraction/reinsertion of $\mathrm{Li}^{+}$. For example, if the cell is charged to $4.8 \mathrm{~V}$, all three $\mathrm{Li}^{+}$ions are extracted from monoclinic $\mathrm{Li}_{3} \mathrm{~V}_{2}\left(\mathrm{PO}_{4}\right)_{3}$ over four two-phase electrochemical plateaus at $3.60 \mathrm{~V}, 3.68 \mathrm{~V}, 4.08 \mathrm{~V}, 4.53 \mathrm{~V}$ during the charge process, which correspond to different phases of $\mathrm{Li}_{x} \mathrm{~V}_{2}\left(\mathrm{PO}_{4}\right)_{3}$ at $x=3.0,2.5,2.0,1.0,0.5$, respectively. Three plateaus at $4.03 \mathrm{~V}, 3.65 \mathrm{~V}, 3.57 \mathrm{~V}$ are observed during the discharge process, which correspond to different phases of $\mathrm{Li}_{x} \mathrm{~V}_{2}\left(\mathrm{PO}_{4}\right)_{3}$ at $x=2.0,1.0,0.5$, respectively. This electrochemical behaviour agrees well with previous results [19, 33].
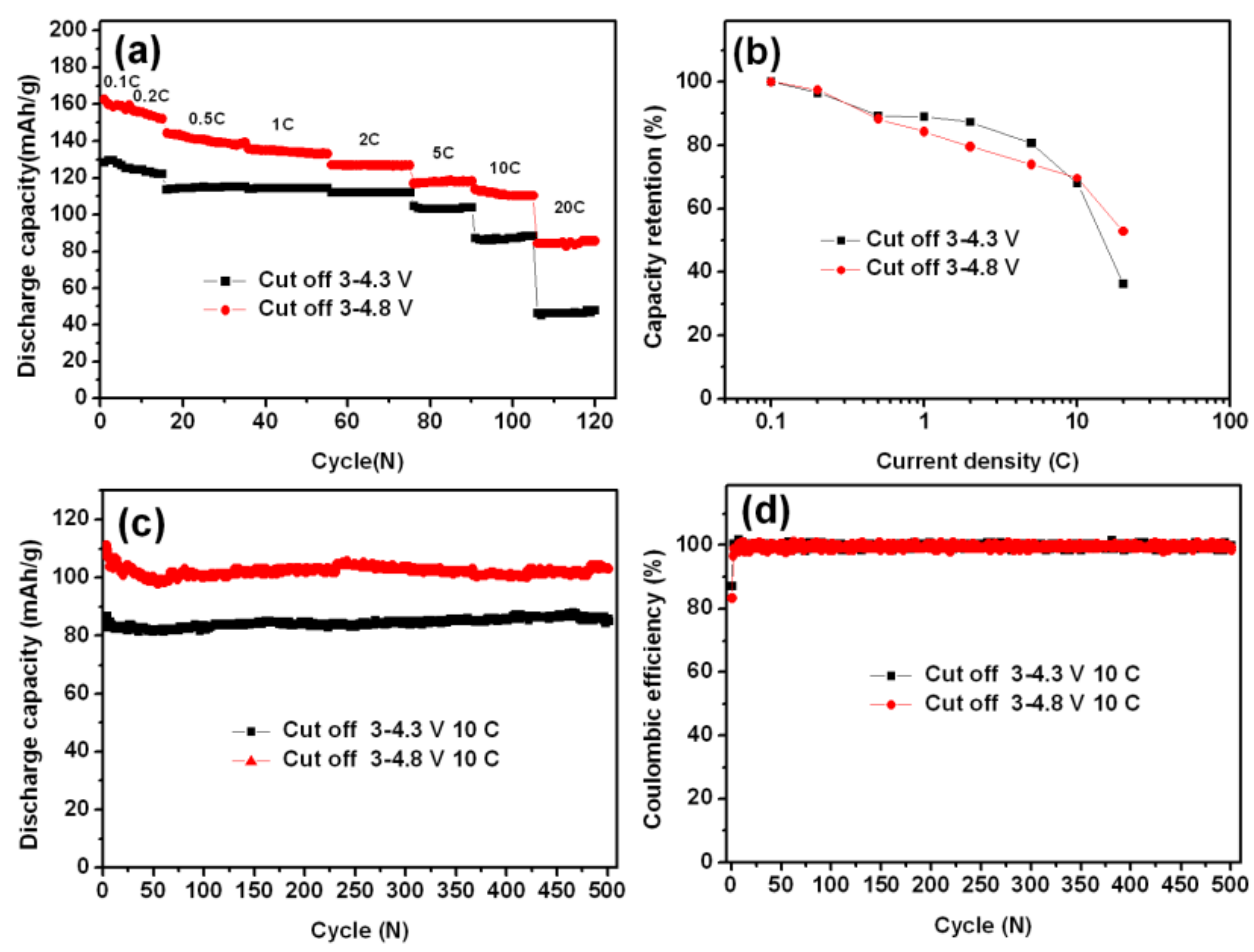

Figure 4. (a) Rate performance of $\mathrm{Li}_{3} \mathrm{~V}_{2}\left(\mathrm{PO}_{4}\right)_{3} / \mathrm{C}$ electrodes; (b) discharge capacity retention at various current densities; (c) cycling performance of $\mathrm{Li}_{3} \mathrm{~V}_{2}\left(\mathrm{PO}_{4}\right)_{3} / \mathrm{C}$, with (d) coulombic efficiency at $10 \mathrm{C}$. 
In order to investigate the rate and cycling performance of $\mathrm{Li}_{3} \mathrm{~V}_{2}\left(\mathrm{PO}_{4}\right)_{3} / \mathrm{C}$, the $\mathrm{Li}_{3} \mathrm{~V}_{2}\left(\mathrm{PO}_{4}\right)_{3} / \mathrm{C}$ cells were charged and discharged for 120 cycles in the voltage ranges of 3.0 4.3 V and 3.0 - $4.8 \mathrm{~V}$, respectively, at various current rates. As shown in Figure 4(a), the first cycle discharge capacity in the voltage range of $3.0-4.3 \mathrm{~V}$ of $\mathrm{Li}_{3} \mathrm{~V}_{2}\left(\mathrm{PO}_{4}\right)_{3} / \mathrm{C}$ at $0.1 \mathrm{C}$ was 128.5 $\mathrm{mAh} \mathrm{g}^{-1}$, while the discharge capacity of $162.7 \mathrm{mAh} \mathrm{g}^{-1}$ was delivered by the $\mathrm{Li}_{3} \mathrm{~V}_{2}\left(\mathrm{PO}_{4}\right)_{3} / \mathrm{C}$ in the voltage range of $3.0-4.8 \mathrm{~V}$ at $0.1 \mathrm{C}$ in the first cycle. After 120 cycles at different C-rates $(0.1-20 \mathrm{C})$, the capacity retention for $\mathrm{Li}_{3} \mathrm{~V}_{2}\left(\mathrm{PO}_{4}\right)_{3} / \mathrm{C}$ measured in the voltage ranges of $3.0-4.3 \mathrm{~V}$ and $3.0-4.8 \mathrm{~V}$ is $36.2 \%$ and $52.9 \%$ of initial capacity, respectively, as shown in Figure 4(b). In Figure 4(c, d), the relatively long-term cycling performance and the coulombic efficiency for $\mathrm{Li}_{3} \mathrm{~V}_{2}\left(\mathrm{PO}_{4}\right)_{3} / \mathrm{C}$ are compared at $10 \mathrm{C}$ in the voltage ranges of $3.0-4.3 \mathrm{~V}$ and $3.0-4.8 \mathrm{~V}$. It can be found in Figure 4(c) that the $\mathrm{Li}_{3} \mathrm{~V}_{2}\left(\mathrm{PO}_{4}\right)_{3} / \mathrm{C}$ has an initial discharge capacity of $86 \mathrm{mAh} \mathrm{g}^{-1}$ and $107.8 \mathrm{mAh} \mathrm{g}^{-1}$ at $10 \mathrm{C}$ in the voltage ranges of $3.0-4.3 \mathrm{~V}$ and $3.0-4.8 \mathrm{~V}$, respectively. Even after 500 cycles, the $\mathrm{Li}_{3} \mathrm{~V}_{2}\left(\mathrm{PO}_{4}\right)_{3} / \mathrm{C}$ cells can still deliver discharge capacities of $85.4 \mathrm{mAh} \mathrm{g}^{-1}$ and $107.8 \mathrm{mAh} \mathrm{g}^{-1}$, with capacity retention of $99.3 \%$ and $95.9 \%$, between $3.0-4.3 \mathrm{~V}$ and $3.0-4.8 \mathrm{~V}$, respectively, indicating the good cycling performance. The $\mathrm{Li}_{3} \mathrm{~V}_{2}\left(\mathrm{PO}_{4}\right)_{3} / \mathrm{C}$ electrodes measured in the voltage ranges of $3.0-4.3 \mathrm{~V}$ and $3.0-4.8 \mathrm{~V}$, however, both present high average coulombic efficiency, approaching $99.5 \%$ at $10 \mathrm{C}$ (Figure 4(d)), indicating that the $\mathrm{Li}_{3} \mathrm{~V}_{2}\left(\mathrm{PO}_{4}\right)_{3} / \mathrm{C}$ has an excellent stable monoclinic structure. The good high rate cycling performance and high coulombic efficiency could be attributed to the 3D network structure of $\mathrm{Li}_{3} \mathrm{~V}_{2}\left(\mathrm{PO}_{4}\right)_{3} / \mathrm{C}$, which could effectively facilitate lithium ion extraction and insertion, leading to the improvement in high rate capacity. Moreover, the long-term cycling stability at high rate of this $\mathrm{Li}_{3} \mathrm{~V}_{2}\left(\mathrm{PO}_{4}\right)_{3} / \mathrm{C}$ compound is much better than those of previous reports using hydrothermal method $[18,19$, 34-37] and microwave assisted method [29, 30]. For examples, Liu et al. [18] reported that nanorod-like $\mathrm{Li}_{3} \mathrm{~V}_{2}\left(\mathrm{PO}_{4}\right)_{3}$ gave a discharge capacity of $101.1 \mathrm{mAh} \mathrm{g}^{-1}$ at $10 \mathrm{C}(1 \mathrm{C}=180 \mathrm{mAh}$ $\mathrm{g}^{-1}$ ) in the voltage of $3.0-4.6 \mathrm{~V}$, but there were no long tern cycling performance for $\mathrm{Li}_{3} \mathrm{~V}_{2}\left(\mathrm{PO}_{4}\right)_{3}$ (only 5 cycles). Qiao et al. [19] found that plate-like $\mathrm{Li}_{3} \mathrm{~V}_{2}\left(\mathrm{PO}_{4}\right)_{3}$ showed a discharge capacity of $111.8 \mathrm{mAh} \mathrm{g}^{-1}$ can still be sustained at $3 \mathrm{C}$ in the voltage of $3.0-4.8 \mathrm{~V}$. However, the cell retains $66.0 \%$ of its initial discharge capacity after 500 cycles. Sun et al. [34] reported that the reversible specific capacity of $\mathrm{Li}_{3} \mathrm{~V}_{2}\left(\mathrm{PO}_{4}\right)_{3}$ was $60 \mathrm{~mA} \mathrm{~h} \mathrm{~g}$ at $5 \mathrm{C}$ in 
the voltage of 3.0 - 4.8 V. Yan et al. [30] employed a fast sol-gel assisted microwave heating approach to prepare $\mathrm{Li}_{3} \mathrm{~V}_{2}\left(\mathrm{PO}_{4}\right)_{3} / \mathrm{C}$ with the particle size ranging from 0.5 to $1.5 \mathrm{~mm}$. The prepared sample $\mathrm{Li}_{3} \mathrm{~V}_{2}\left(\mathrm{PO}_{4}\right)_{3} / \mathrm{C}$ delivered a reversible discharge capacity of $100 \mathrm{mAh} \mathrm{g}^{-1}$ after 100 cycles at $20 \mathrm{C}$ in the voltage of $3.0-4.3 \mathrm{~V}$, exhibiting excellent rate capability and cycling performance. However, there was no report on the long term test for $\mathrm{Li}_{3} \mathrm{~V}_{2}\left(\mathrm{PO}_{4}\right)_{3} / \mathrm{C}$.
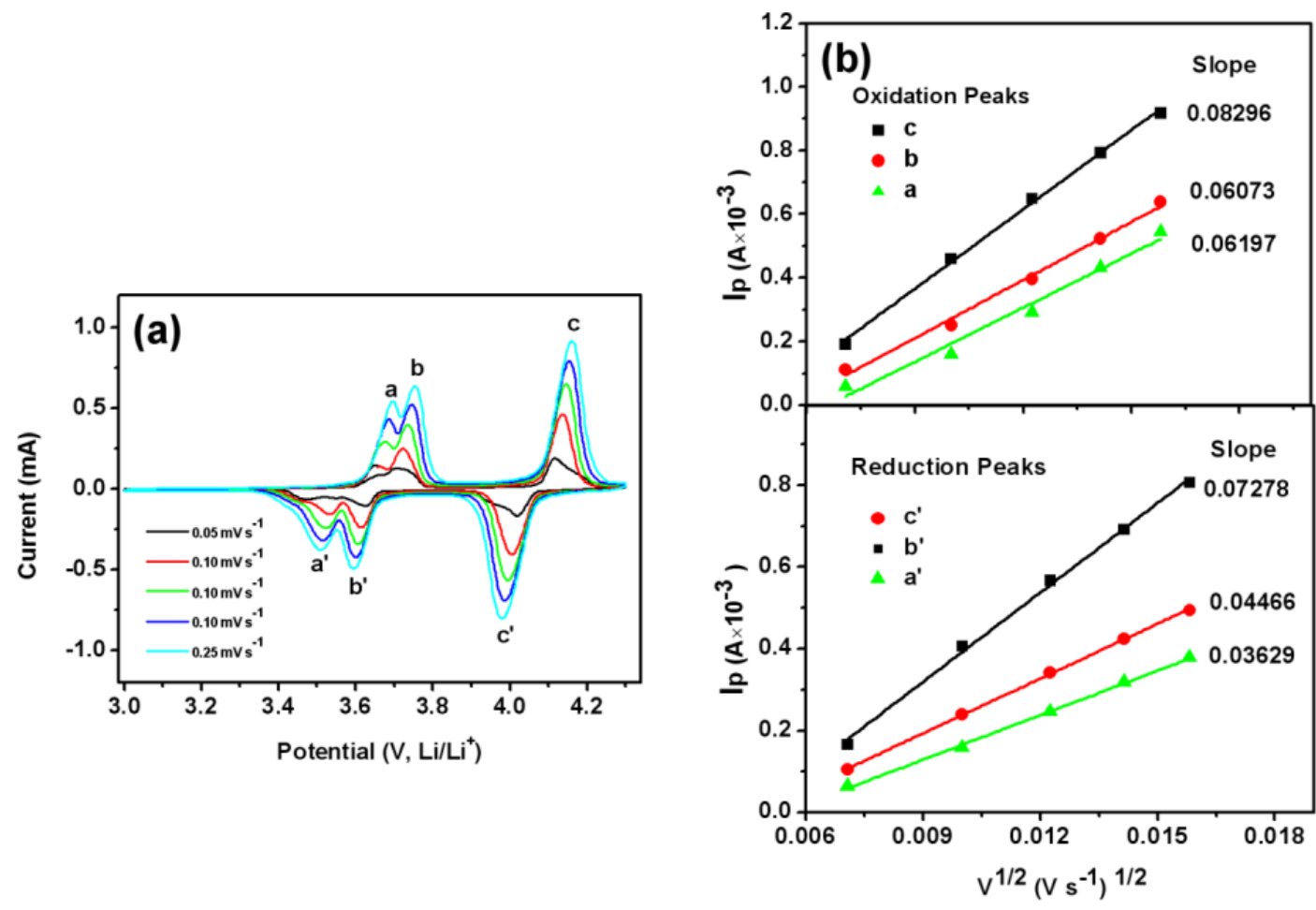

Figure 5. (a) Cyclic voltammograms of $\mathrm{Li}_{3} \mathrm{~V}_{2}\left(\mathrm{PO}_{4}\right)_{3} / \mathrm{C}$ at different scan rates from 0.05 to $0.25 \mathrm{mV} \mathrm{s}^{-1}$. (b) Linear fits of the peak current $i_{\mathrm{p}}$ for the oxidation and reduction peaks as functions of the square root of the scan rate $\left(v^{1 / 2}\right)$.

The cyclic voltammetry (CV) technique is widely employed to estimate the $\mathrm{Li}^{+}$ diffusion coefficient $[19,32,33]$. Figure 5(a) shows the $\mathrm{CV}$ of $\mathrm{Li}_{3} \mathrm{~V}_{2}\left(\mathrm{PO}_{4}\right)_{3} / \mathrm{C}$ at various scan rates in the voltage range of $3.0-4.3 \mathrm{~V}$ : the peaks of $a / a^{\prime}, b / b^{\prime}$ and $c / c^{\prime}$ correspond to the 0.5 , 0.5 and $1 \mathrm{Li}$ extraction/reinsertion, respectively. Figure 5(b) show the fitted line plots of the peak current $\left(i_{\mathrm{p}}\right)$ of the $\mathrm{CV}$ as a function of the square root of the scan rate $\left(v^{1 / 2}\right)$, indicating diffusion-controlled behaviour. The diffusion coefficient of $\mathrm{Li}^{+}$could be calculated based on Equations (1) and (2), expressed as 
$i_{\mathrm{p}}=2.69 \times 10^{5} n^{3 / 2} A D^{1 / 2} v^{1 / 2} C_{0}^{*}$

$\mathrm{D}=\left(i_{\mathrm{p}} / v^{1 / 2}\right) /\left(2.69 \times 10^{5} n^{3 / 2} A C_{0}{ }^{*}\right)=\left[\mathrm{k} /\left(2.69 \times 10^{5} n^{3 / 2} A C_{0}{ }^{*}\right)\right]^{2}$

where $\mathrm{k}$ is the slope of the linear fit of the peak current $i_{p}$ as a function of the square root of the scan rate $\left(v^{1 / 2}\right), n$ is the number of electrons per reaction species, $\mathrm{A}$ is the surface area of the electrode $\left(\mathrm{cm}^{2}\right), D$ is the diffusion coefficient of $\mathrm{Li}^{+}\left(\mathrm{cm}^{2} \mathrm{~s}^{-1}\right), C_{0} *$ is the concentration of lithium ions corresponding to the different specific electrochemical reaction steps $\left(\mathrm{mol} \mathrm{cm}{ }^{-3}\right)$. For the $\mathrm{Li}^{+}$diffusion in the electrode, $C_{0} *$ is calculated as $3.687 \times 10^{-3} \mathrm{~mol} \mathrm{~cm}^{-3}$, the numbers of Li per unit cell divided by the volume of cell (900.927(3) $\AA^{3}$ ). Therefore, according to Eq. (2), the $\mathrm{Li}^{+}$diffusion coefficient $D_{\mathrm{s}}$ in the solid state cathode electrode and the electrolyte were calculated and are listed in Table 2. The $\mathrm{Li}$ ion diffusion coefficient of the $\mathrm{Li}_{3} \mathrm{~V}_{2}\left(\mathrm{PO}_{4}\right)_{3} / \mathrm{C}$ is calculated to be on the order of $\sim 10^{-9} \mathrm{~cm}^{2} \mathrm{~s}^{-1}$, which is very close to Liu et al. results [33], which present excellent cycling performance on the carbon coated- $\mathrm{Li}_{3} \mathrm{~V}_{2}\left(\mathrm{PO}_{4}\right)_{3}$ and nanocomposite $\mathrm{Li}_{3} \mathrm{~V}_{2}\left(\mathrm{PO}_{4}\right)_{3} /$ graphene. Therefore, the 3D network structure of $\mathrm{Li}_{3} \mathrm{~V}_{2}\left(\mathrm{PO}_{4}\right)_{3} / \mathrm{C}$ shows good kinetic properties for the lithium diffusion during the charge/discharge processes, leading to its excellent rate capabilities and cycling performance.

Table 2. The calculated lithium diffusion coefficients for $\mathrm{Li}_{3} \mathrm{~V}_{2}\left(\mathrm{PO}_{4}\right)_{3} / \mathrm{C}$.

\begin{tabular}{ccc}
\hline $\mathrm{Li}_{3} \mathrm{~V}_{2}\left(\mathrm{PO}_{4}\right)_{3} / \mathrm{C}$ & Peak & $\mathrm{D}_{\mathrm{s}}\left(10^{-9} \mathrm{~cm}^{2} \mathrm{~s}^{-1}\right)$ \\
\hline & $\mathrm{c}$ & 7.00 \\
\cline { 2 - 3 }$($ Oxidation & $\mathrm{b}$ & 7.50 \\
\cline { 2 - 3 } & $\mathrm{a}$ & 6.09 \\
\hline Reduction & $\mathrm{c}^{\prime}$ & 5.38 \\
\cline { 2 - 3 }$($ discharge $)$ & $\mathrm{b}^{\prime}$ & 4.06 \\
\hline
\end{tabular}



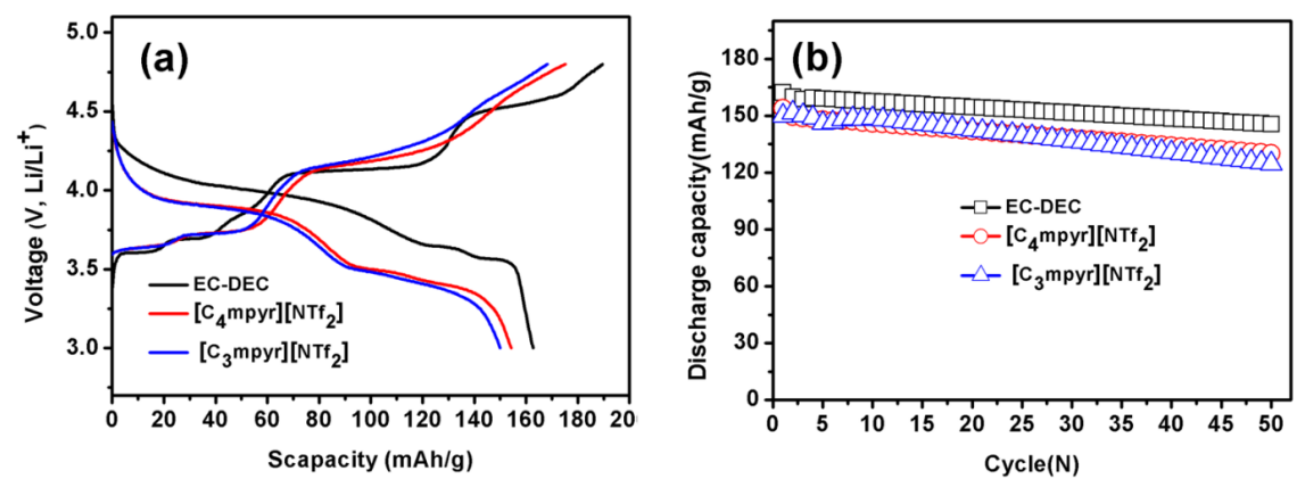

Figure 6. (a) Initial charge/discharge profiles and (b) cycling performances of $\mathrm{Li}_{3} \mathrm{~V}_{2}\left(\mathrm{PO}_{4}\right)_{3}$ electrodes measured with different electrolytes at the $0.1 \mathrm{C}$ rate in the voltage of $3.0-4.8 \mathrm{~V}$ at room temperature.

Figure 6(a) shows the initial charge-discharge profiles obtained with the $\mathrm{Li}_{3} \mathrm{~V}_{2}\left(\mathrm{PO}_{4}\right)_{3} / \mathrm{C}$ electrode in the conventional and ionic liquid electrolytes at the $0.1 \mathrm{C}$ rate in the voltage of $3.0-4.8 \mathrm{~V}$ at room temperature. The $\mathrm{Li}_{3} \mathrm{~V}_{2}\left(\mathrm{PO}_{4}\right)_{3} / \mathrm{C}$ delivered higher discharge capacity in conventional electrolyte, $162.3 \mathrm{mAh} \mathrm{g}^{-1}$, than in the ionic liquids, $153.9 \mathrm{mAh} \mathrm{g}^{-1}$ and 150.1 $\mathrm{mAh} \quad \mathrm{g}^{-1}$ for $\left[\mathrm{C}_{4} \mathrm{mpyr}\right]\left[\mathrm{NTf}_{2}\right]$ and $\left.\left[\mathrm{C}_{3} \mathrm{mpyr}\right]\left[\mathrm{NTf}_{2}\right]\right)$ electrolytes, respectively. The $\mathrm{Li}_{3} \mathrm{~V}_{2}\left(\mathrm{PO}_{4}\right)_{3} / \mathrm{C}$ delivered higher initial coulombic efficiency, however, in $1 \mathrm{M} \operatorname{LiNTf}_{2}$ in $\left[\mathrm{C}_{4} \mathrm{mpyr}\right]\left[\mathrm{NTf}_{2}\right]$ and $\left[\mathrm{C}_{3} \mathrm{mpyr}\right]\left[\mathrm{NTf}_{2}\right]$ electrolytes, $82.5 \%$ and $81.2 \%$, respectively, which are both higher than in conventional electrolyte, $79.8 \%$. The high initial columbic efficiency indicated the highly reversible nature of the reaction for $\mathrm{Li}_{3} \mathrm{~V}_{2}\left(\mathrm{PO}_{4}\right)_{3}$ cycled in $1 \mathrm{M} \mathrm{LiNTf}$ in $\left[\mathrm{C}_{4} \mathrm{mpyr}\right]\left[\mathrm{NTf}_{2}\right]$ and $\left[\mathrm{C}_{3} \mathrm{mpyr}\right]\left[\mathrm{NTf}_{2}\right]$ ionic liquid electrolytes. The cycling performance of the $\mathrm{Li}_{3} \mathrm{~V}_{2}\left(\mathrm{PO}_{4}\right)_{3} / \mathrm{C}$ electrodes measured in the conventional and ionic liquid electrolytes is shown in Figure 6(b). The discharge capacity at the $50^{\text {th }}$ cycle of $\mathrm{Li}_{3} \mathrm{~V}_{2}\left(\mathrm{PO}_{4}\right)_{3}$ is still retained at about $145.6 \mathrm{mAh} \mathrm{g}^{-1}, 130.1 \mathrm{mAh} \mathrm{g}^{-1}$, and $124.7 \mathrm{mAh} \mathrm{g}^{-1}$, with $89.7 \%, 84.5 \%$, and $83.1 \%$ capacity retention, in the conventional electrolyte, and the $\left[\mathrm{C}_{3} \mathrm{mpyr}\right]\left[\mathrm{NTf}_{2}\right]$ and $\left[\mathrm{C}_{4} \mathrm{mpyr}\right]\left[\mathrm{NTf}_{2}\right]$ ionic electrolytes, respectively. These cycling performance results indicate that the $\mathrm{Li}_{3} \mathrm{~V}_{2}\left(\mathrm{PO}_{4}\right)_{3}$ could be cycled in the high voltage range in the high ionic conductivity, non-flammable ionic electrolytes. 


\section{Conclusions}

A high performance at high $\mathrm{C}$ rates $\mathrm{Li}_{3} \mathrm{~V}_{2}\left(\mathrm{PO}_{4}\right)_{3}$ cathode material for lithium ion batteries was synthesized by the high efficient and low cost microwave assisted hydrothermal method, followed by a post-annealing process. Electrochemical results showed that the $\mathrm{Li}_{3} \mathrm{~V}_{2}\left(\mathrm{PO}_{4}\right)_{3}$ electrode measured at $10 \mathrm{C}$ after 500 cycles can still deliver discharge capacities of $85.4 \mathrm{mAh}$ $\mathrm{g}^{-1}$ and $107.8 \mathrm{mAh} \mathrm{g}^{-1}$, with capacity retention of $99.3 \%$ and $95.9 \%$, between $3.0-4.3 \mathrm{~V}$ and $3.0-4.8 \mathrm{~V}$, respectively, indicating the good discharge capacity and cycling stability. Furthermore, the $\mathrm{Li}_{3} \mathrm{~V}_{2}\left(\mathrm{PO}_{4}\right)_{3}$ can be cycled at $0.1 \mathrm{C}$ in the voltage range of $3.0-4.8 \mathrm{~V}$ in the high ionic conductivity, non-flammable ionic liquid electrolytes, with relative acceptable capacities retention. Therefore, the ionic liquid electrolytes could be a good choice to address the problems of electrolyte degradation for high voltage cathodes $(\geq 4.6 \mathrm{~V})$ and increase the operating safety of lithium ion batteries.

\section{Acknowledgements}

Financial support was provided by the Australian Research Council through a Discovery project (DP110103909). The authors thank Dr. T. Silver for critical reading of the manuscript.

\section{References}

[1] A.K. Padhi, K.S. Nanjundaswamy, J.B. Goodenough, J. Electrochem. Soc. 144 (1997) $1188-1194$

[2] B. Scrosati, J. Hassoun, Y.-K. Sun, Energy Environ. Sci. 4 (2011) 3287-3295.

[3] C.A.J. Fisher, V.M. Hart Prieto, M.S. Islam, Chem. Mater. 20 (2008) 5907-5915.

[4] L. Dimesso, C. Forster, W. Jaegermann, J.P. Khanderi, H. Tempel, A. Popp, J. Engstler, J.J. Schneider, A. Sarapulova, D. Mikhailova, L.A. Schmitt, S. Oswald, H. Ehrenberg, Chem. Soc. Rev. 41 (2012) 5068-5080.

[5] H. Huang, S.C. Yin, T. Kerr, N. Taylor, L.F. Nazar, Adv. Mater. 14 (2002) 1525-1528.

[6] M.Y. Saidi, J. Barker, H. Huang, J.L. Swoyer, G. Adamson, J. Power Sources 119 (2003) 266-272. 
[7] M.M. Ren, Z. Zhou, L.W. Su, X.P. Gao, J. Power Sources 189 (2009) 786-789.

[8] L. Wang, L.B. Yang, L. Gong, X.Q. Jiang, K. Yuan, Z.B. Hu, Electrochim. Acta 56 (2011) 6906-6911.

[9] J. Xu, Y. Zhao, Q. Kuang, Y. Dong, Electrochim. Acta 56 (2011) 6562-6567.

[10] Q. Kuang, Y. Zhao, J. Xu, J. Phys. Chem. C 115 (2011) 8422-8429.

[11] L. Adam, A. Guesdon, B. Raveau, J. Solid State Chem. 181 (2008) 3110-3115.

[12] S.-i. Nishimura, M. Nakamura, R. Natsui, A. Yamada, J. Amer. Chem. Soc. 132 (2010) $13596-13597$.

[13] H. Kim, I. Park, D.-H. Seo, S. Lee, S.-W. Kim, W.J. Kwon, Y.-U. Park, C.S. Kim, S. Jeon, K. Kang, J. Amer. Chem. Soc. 134 (2012) 10369-10372.

[14] R.A. Shakoor, H. Kim, W. Cho, S.Y. Lim, H. Song, J.W. Lee, J.K. Kang, Y.-T. Kim, Y. Jung, J.W. Choi, J. Amer. Chem. Soc. 134 (2012) 11740-11748.

[15] K. Trad, D. Carlier, L. Croguennec, A. Wattiaux, B. Lajmi, M. Ben Amara, C. Delmas, J. Phys. Chem. C 114 (2010) 10034-10044.

[16] H. Huang, S.C. Yin, T. Kerr, N. Taylor, L.F. Nazar, Adv. Mater. 14 (2002) 1525-1528.

[17] Q.Q. Chen, T.T. Zhang, X.C. Qiao, D.Q. Li, J.W. Yang, J. Power Sources 234 (2013) 197-200.

[18] H.W. Liu, C.X. Cheng, X.T. Huang, J.L. Li, Electrochim. Acta 55 (2010) 8461-8465.

[19] Y.Q. Qiao, X.L. Wang, Y.J. Mai, J.Y. Xiang, D. Zhang, C.D. Gu, J.P. Tu, J. Power Sources 196 (2011) 8706-8709.

[20] A.Q. Pan, D.W. Choi, J.G. Zhang, S.Q. Liang, G.Z. Cao, Z.M. Nie, B.W. Arey, J. Liu, J. Power Sources 196 (2011) 3646-3649.

[21] X.H. Rui, D.H. Sim, K.M. Wong, J.X. Zhu, W.L. Liu, C. Xu, H.T. Tan, N. Xiao, H.H. Hng, T.M. Lim, Q.Y. Yan, J. Power Sources 214 (2012) 171-177.

[22] S. Lee, Y. Cho, H.-K. Song, K.T. Lee, J. Cho, Angew. Chem. Inter. Ed. 51 (2012) 8748-8752.

[23] J.T. Xu, S.L. Chou, M. Avdeev, M. Sale, H.K. Liu, S.X. Dou, Electrochim. Acta 88 (2013) 865-870.

[24] J. Xiang, F. Wu, R.J. Chen, L. Li, H.G. Yu, J. Power Sources 233 (2013) 115-120.

[25] H. Kim, Y. Ding, P.A. Kohl, J. Power Sources 198 (2012) 281-286. 
[26] A.V. Murugan, T. Muraliganth, A. Manthiram, J. Phys. Chem. C 112 (2008) $14665-14671$.

[27] C.-Y. Cao, Z.-M. Cui, C.-Q. Chen, W.-G. Song, W. Cai, J. Phys. Chem. C 114 (2010) 9865-9870.

[28] Y. Wang, H. Zhao, J. Gao, G. Zhao, Y. Zhang, Y. Zhang, J. Phys. Chem. C 116 (2012) 7457-7463.

[29] G. Yang, H.D. Liu, H.M. Ji, Z.Z. Chen, X.F. Jiang, J. Power Sources 195 (2010) $5374-5378$

[30] J. Yan, W.F. Mao, H. Xie, Z.Y. Tang, W. Yuan, X.C. Chen, Q. Xu, L. Ma, Mater. Res. Bull. 47 (2012) 1609-1612.

[31] Y.H. Chen, Y.M. Zhao, X.N. An, J.M. Liu, Y.Z. Dong, L. Chen, Electrochim. Acta 54 (2009) 5844-5850.

[32] X.H. Rui, N. Ding, J. Liu, C. Li, C.H. Chen, Electrochim. Acta 55 (2010) 2384-2390.

[33] H.D. Liu, G. Yang, X.F. Zhang, P. Gao, L. Wang, J.H. Fang, J. Pinto, X.F. Jiang, J. Mater. Chem. 22 (2012) 11039-11047.

[34] C.W. Sun, S. Rajasekhara, Y.Z. Dong, J.B. Goodenough, Acs. Appl. Mater. Inter. 3 (2011) 3772-3776.

[35] C.X. Chang, J.F. Xiang, X.X. Shi, X.Y. Han, L.J. Yuan, J.T. Sun, Electrochim. Acta 54 (2008) 623-627.

[36] Y.Q. Qiao, J.P. Tu, J.Y. Xiang, X.L. Wang, Y.J. Mai, D. Zhang, W.L. Liu, Electrochim. Acta 56 (2011) 4139-4145.

[37] F. Teng, Z.H. Hu, X.H. Ma, L.C. Zhang, C.X. Ding, Y. Yu, C.H. Chen, Electrochim. Acta 91 (2013) 43-49. 